\title{
ISOLATION OF BOVINE CORONAVIRUS (BCoV) IN MONOLAYERS OF HmLu-1 CELLS
}

\author{
José Antonio Jerez ${ }^{1 *}$; Fábio Gregori ${ }^{1}$; Paulo Eduardo Brandão ${ }^{1}$; Cesar Alejandro Rosales Rodriguez ${ }^{1}$; \\ Fumio Honma Ito ${ }^{1}$; Maria da Glória Buzinaro² ${ }^{2}$ Takeo Sakai $^{3}$
}

${ }^{1}$ Departamento de Medicina Veterinária Preventiva e Saúde Animal, Universidade de São Paulo, São Paulo, SP, Brasil; ${ }^{2}$ Departamento de Medicina Veterinária Preventiva e Reprodução Animal, Universidade Estadual Paulista, Jaboticabal, SP, Brasil; ${ }^{3}$ Department of Preventive Veterinary Medicine and Animal Health, College of Bioresource Sciences, Nihon University, Japan

Submitted: August 20, 2004; Returned to authors for corrections: July 20, 2005; Approved: August 05, 2005

\begin{abstract}
Isolation of $\mathrm{BCoV}$ was performed in monolayers of $\mathrm{HmLu}-1$ cells, using 20 fecal samples from clinical cases of diarrhea in calves. Samples were positive for $\mathrm{BCoV}$ by means of hemagglutination / hemagglutination inhibition (HA/HI). Up to the fifth serial passage, 13 of these isolates presented syncytial cytopathic effect, similar to Kakegawa standard strain. When isolates were submitted to seroneutralization with gammaglobulin antibovine coronavirus, 8 of them were considered to be positive, once cytopathic effect was neutralized. After titration and seroneutralization in microplates, only three of them were confirmed as positive. The lineage HmLu-1 showed higher permissivity to $\mathrm{BCoV}$ isolation, but the low intensity of viral replication demonstrated that new methodologies should be developed for this purpose and then submitted to confirmation of isolation by means of seroneutralization.
\end{abstract}

Key words: bovine coronavirus (BCoV), isolation, HmLu-1 cells

\section{INTRODUCTION}

Bovine coronavirus (BCoV) was described for the first time in 1973 by Mebus et al. (12). It is involved in the etiology of neonatal diarrhea in calves and winter dysentery of adult cows in many countries, including Brazil $(3,9,16,18)$. It may also be involved in infections of the respiratory tract in calves $(2,20)$.

Coronavirus genus, in the family Coronaviridae and order Nidovirales, is subdivided into three groups, distributed as a function of their natural hosts, serological reactions (epitopes present in the glycoprotein of the envelope) and sequence of nucleotides of single stranded, positive polarity RNA. BCoV belongs to group $2(2,5)$.

The involvement of coronavirus in severe acute respiratory syndrome (SARS), which does not belong to any of the three groups known nowadays $(11,14)$ increased both the interest on the main antigenic properties of coronavirus and the importance of its culture in laboratory. Coronavirus culture is very problematic and limits the knowledge of its antigenic properties.

$\mathrm{BCoV}$ was initially isolated in primary culture of bovine kidney (12) and after that, propagated in several cell lineages: BEK-1 (Bovine embryonic kidney), VERO (African green monkey kidney), MDBK (Madin-Darby bovine kidney), $\mathrm{PK}_{-15}$ (Porcine kidney), $\mathrm{D}_{2} \mathrm{BFS}$ (Bovine fetal spleen), BEL (Bovine embryonic lung) and HRT-18 (Human rectal tumor) $(1,6,7,19$, 20,21). HRT- ${ }_{18}$ is the most sensitive lineage to be used in primary isolation, mainly in the presence of trypsin (1) and respiratory samples (20).

Kakegawa strain, isolated in primary culture of bovine kidney from fecal material of adult cow presenting winter dysentery (18), was adapted to culture in HmLu-1 (Hamster lung) cells by Dr. Y. Inaba, from the National Institute of Animal Health, Tsukuba, Ibakari, Japan. As there is no report on the isolation of $\mathrm{BCoV}$ in this cell lineage, the objective of the present trial

*Corresponding Author. Mailing address: FMVZ - USP - VPS. Av. Prof. Dr. Orlando Marques de Paiva, 87, Cidade Universitária. 05508-900, São Paulo, SP, Brasil. E-mail: jajerez@usp.br 
was to assess permissivity of these cells to isolation of the virus in samples of fecal material positive for $\mathrm{BCoV}$, collected from clinical cases of diarrhea in calves.

\section{MATERIALS AND METHODS}

\section{Fecal samples}

Initially, 96 samples of fecal material were collected from calves of 1 day to 4 months old and presenting clinical signs of diarrhea. Animals were kept in different dairy farms in 12 cities of São Paulo state, Brazil.

Fecal samples were submitted to laboratory diagnosis of bovine coronavirus by hemagglutionation / hemagglutionation inhibition (HA/HI), according to the method recommended by Sato et al (15), with the modifications described in a previous report (9).

From the samples positive in $\mathrm{HA} / \mathrm{HI}, 20$ were chosen at random in order to attempt isolation in cell culture.

\section{Standard strain}

Kakegawa strain of bovine coronavirus, adapted to culture in $\mathrm{HmLu}-1$ cells was used as the standard.

\section{Cell culture}

Monolayers of HmLu-1 (Hamster lung) cells adapted to growth in Minimum Essential Medium Eagle (MEM - Cultilab®) with $10 \%$ of bovine fetal serum (Cultilabß) were used.

\section{Gammaglobulin anti-bovine coronavirus}

Serum of hyperimmunized sheep was used in a semi-purified preparation of Kakegawa strain. Sera were submitted to precipitation with ammonium sulfate $35 \%$ according to the method described by Herbert et al (8), for the purification of gammaglobulin fraction.

\section{Preparation of fecal material}

A suspension of fecal material was prepared in a 1:4 proportion (p/v) in PBS/BSA (PBS 0.01 M pH 7.2 and 0.1\%BSA), centrifuged at $12,000 \mathrm{~g}$ under refrigeration for 30 minutes. Supernatant was filtered in a $0.22 \mu \mathrm{m}$ Millex ${ }^{\circledR}$ system.

\section{Inoculation in cell culture}

One $\mathrm{mL}$ of the filtered fecal suspension was inoculated, in triplicate, in HmLu-1 monolayers with 48 hours of growth in plastic bottles $\left(25 \mathrm{~cm}^{2}\right)$. Previous growth medium was discarded and monolayers were washed twice in MEM before the inoculation.

After 1 hour of adsorption under stirring at $37^{\circ} \mathrm{C}$, the inoculum was discarded. Eight mL of MEM (without serum) were added.

Bottles were incubated at $37^{\circ} \mathrm{C}$ and cytopathic effect was observed until 96 hours after inoculation. Monolayers were then frozen for the next passages, which were performed with 1 $\mathrm{mL}$ of the respective previous passage.

As the negative control, inoculum with PBS/BSA was used and, as positive control, Kakegawa strain.

Isolates were considered positive when they presented syncytial cytopathic effect similar to the Kakegawa strain until the fifth serial passage.

\section{Seroneutralization reaction}

Positive isolates were submitted to seroneutralization in order to confirm isolation of $\mathrm{BCoV}$.

Initially, in duplicate, $1 \mathrm{~mL}$ of anti-bovine coronavirus gammaglobulin (item 4) was added to $1 \mathrm{~mL}$ of each isolate, and incubated in water bath at $37^{\circ} \mathrm{C}$ for 1 hour. After that, inoculation in $\mathrm{HmLu}-1$ cells was performed using the same procedure described previously (item 6). Isolate was confirmed as positive for BCoV when no cytopathic effect was observed.

Later on, isolates were submitted to seroneutralization in 96-well microplates. In duplicate, isolates in MEM (without serum) were diluted from $10^{-1}$ to $10^{-8}$ for end point titration. In other plates, the same procedure was repeated, adding to each well $100 \mu \mathrm{L}$ of anti-bovine coronavirus gammaglobulin (item 4) in the optimum dilution to neutralize 100 DICT of Kakegawa strain. These mixtures were incubated for 1 hour at $37^{\circ} \mathrm{C}$.

Isolates prepared were transferred to 96-well microplates with monolayers of HmLu-1 cells with 48 hours of growth. Microplates were incubated at $37^{\circ} \mathrm{C}$ and $5 \%$ of $\mathrm{CO}_{2}$ for 96 hours.

Isolates were considered to be positive for $\mathrm{BCoV}$ when they presented a two-fold decrease in titer, between titration and seroneutralization.

\section{RESULTS}

Among samples studied for the presence of BCoV by means of HA/HI, 42 were positive. From the 20 samples positive in $\mathrm{HA} / \mathrm{HI}$ tested to isolate the virus in $\mathrm{HmLu}-1$ cells, 13 (13/20 = $65 \%$ ) presented syncytial cytopathic effect similar to the Kakegawa strain, until the fifth passage (Fig. 1). When submitted to initial seroneutralization, $8(8 / 20=40 \%)$ were positive, once the gammaglobuline fraction anti-bovine coronavirus was able to neutralize the cytopathic effect.

When titration of the 13 isolates was performed, it was observed that 8 of them presented titer equal to $10^{2}$, and the others presented titers lower or equal to $10^{1}$. The seroneutralization in microplates indicated that $3(3 / 20=15 \%)$ of the isolates were confirmed as positive for $\mathrm{BCoV}$.

\section{DISCUSSION}

Due to the difficulty of BCoV to grow in cell cultures, there are few reports on the isolation of this virus. HRT- ${ }_{18}$ cell lineage, in the presence of trypsin, is considered to be the most sensitive 

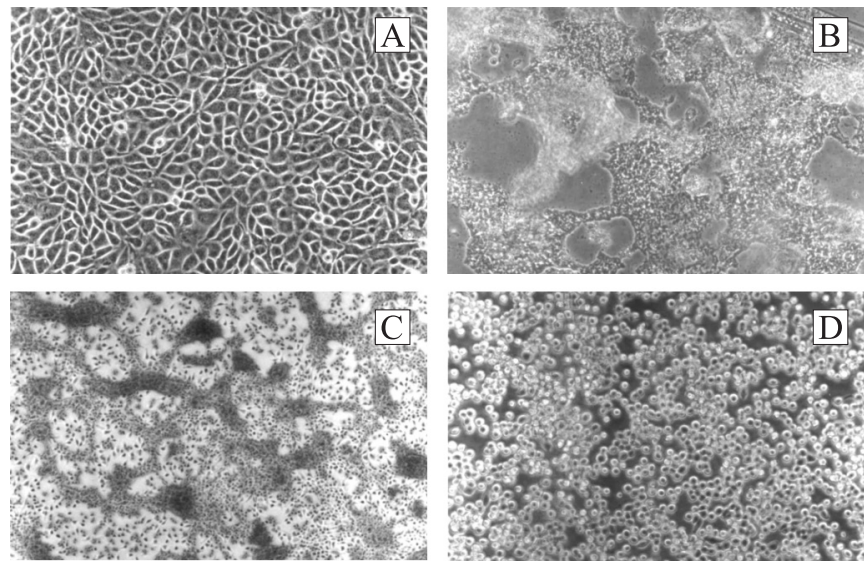

Figure 1. Optical photomicrography (100X) of monolayers of HmLu-1 cells: a) 48 hours of growth, adequate for inoculation of field samples. b) Kakegawa standard sample, 48 hours after inoculation. c) Field sample (63/01), 96 hours after inoculation, later confirmed as $\mathrm{BCoV}$. d) Cytotoxic effect of field sample (36/01), 48 hours after inoculation, not confirmed as BCoV.

for primary isolation (1,20). Benfield and Saif (1) successfully worked with only one isolate based on fecal material and nasal secretions of gnotobiotic calves inoculated with fecal material obtained from an adult cow with symptoms of winter dysentery. Tsunemitsu et al. (20), in 180 samples collected from calves, obtained 5 isolates (3\%) from fecal material and 56 (31\%) from nasal secretions.

In the present study, cell lineage HmLu-1 showed greater permissivity. In 20 fecal samples collected from clinical cases of diarrhea in calves, and positive for $\mathrm{BCoV}$ by means of $\mathrm{HA} / \mathrm{HI}$ (9), it was possible to observe that $13(65 \%)$ presented syncytial cytopathic effect compatible with $\mathrm{BCoV}$, similar to the Kakegawa strain, until the fifth serial passage (Fig. 1).

The limit of five serial passages was determined in order to adequate costs and operationally, once in some of the samples cultured until the tenth serial passage no cytopathic effect was observed (data not shown). Besides, in most samples, cytotoxic effect observed in the first passage was very intense (Fig.1), what may have compromised virus-cell interaction and, consequently, the whole process of viral reduplication.

Seroneutralization in bottles using gammaglobulin antibovine coronavirus confirmed the specific presence of $\mathrm{BCoV}$ in $8(40 \%)$ of the 13 isolates that presented cytopathic effect.

The absence of confirmation in the other isolates may be explained by several hypotheses, but the most probable one would be a viral concentration impossible to be neutralized by gammaglobulin anti-bovine coronavirus fraction.

In titration of the isolates, the greatest titers observed were equal to $10^{2}$, what does not confirm the hypothesis of high viral concentration. Thus, seroneutralization in microplates was able to confirm the isolation of only three isolates that presented cytopathic effect.

In spite of the higher permissivity, the low intensity of viral replication in $\mathrm{HmLu}-1$ cells was the limiting factor for the actual confirmation of $\mathrm{BCoV}$ isolation, by means of seroneutralization.

The infectivity of BCoV may be increased by the addition of proteolytic enzymes, as it was observed in several cell lineages $(1,6,7,10)$. However, lineage $\mathrm{HmLu}-1$ showed to be labile to very low concentrations of trypsin, such as $5 \mu \mathrm{g} / \mathrm{mL}$ of medium (data not shown).

Apparently, the result of seroneutralization in bottles was better than in microplates. However, monolayers cultured in microplates tend to degenerate faster than monolayers in bottles of $25 \mathrm{~cm}^{2}$, due to their small area and availability of medium, and the need to use $\mathrm{CO}_{2}$ chambers in incubation. Therefore, isolates may be considered to be negative due to monolayer degeneration, before seroneutralization could be observed.

Although viral replication was of low intensity, and discrepant results of seroneutralization in bottles and microplates were observed, differences in serological behavior of $\mathrm{BCoV}$ have already been reported: reactivity in relation to a panel of monoclonal antibodies (13), different values in relation to crossed seroneutralization between homologous and heterologous samples (21) and results of HI, as well as the susceptibility or resistance to higromicine B in samples isolated from eight North American states (10).

This difference in serological behavior may be associated with protein S ("spike" - $180 \mathrm{kDa}$ ), main structural protein of coronavirus, which is responsible for the induction of neutralizing antibodies $(2,5)$. In $\mathrm{BCoV}$, it may be cleaved in subunits $S_{1}$ and $S_{2}$. Ectodomain $S_{1}$ presents a region of hypervariability (4). Exchange of aminoacids in such an important region for coronavirus antigenicity is greatly used in the study of SARS, because most mutations occur in this subunity $(17,22)$.

Ectodomain $\mathrm{S}_{2}$ is the carboxyl-terminal portion of the protein, responsible for the fusion of the membrane and formation of syncytia $(2,4,5)$. The observation of cytopathic effect compatible with $\mathrm{BCoV}$ shows high permissivity to isolation in $\mathrm{HmLu}-1$ cells.

Although the intensity of viral replication is low, making impossible to confirm the isolation by means of seroneutralization, the permissivity of $\mathrm{HmLu}-1$ to infection by $\mathrm{BCoV}$ observed in the present study shows perspectives for new studies on the increase of intensity of viral replication in this cell lineage, what may contribute for greater knowledge of $\mathrm{BCoV}$ antigenic properties and consequently, of the epidemiological chain of bovine coronavirosis.

\section{ACKNOWLEDGEMENTS}

This research was supported by FAPESP (Fundação de Amparo à Pesquisa do Estado de São Paulo), process \# 00/091209. We thank the Laboratório Bio-Vet S.A. for technical support. 


\section{RESUMO}

\section{Isolamento de coronavírus bovino ( $\mathrm{BCoV}$ ) em monocamada de cultura de células da linhagem HmLu-1}

A partir de 20 amostras fecais de bezerros, com quadro clínico de diarréia, positivas para $\mathrm{BCoV}$ por hemaglutinação/inibição da hemaglutinação (HA/HI), procedeu-se o isolamento viral em monocamadas de células da linhagem HmLu-1. Até a quinta passagem seriada, 13 apresentaram efeito citopático do tipo sincicial, semelhante à amostra padrão Kakegawa de $\mathrm{BCoV}$. Ao serem submetidas a uma reação de soroneutralização com gamaglobulina anti-coronavírus bovino, 8 delas foram consideradas positivas, uma vez que o efeito citopático foi neutralizado. Ao serem tituladas e submetidas à reação de soroneutralização em microplacas, apenas 3 delas puderam ser confirmadas como positivas. As células da linhagem HmLu-1 mostraram-se permissivas para o isolamento de $\mathrm{BCoV}$, todavia a baixa intensidade na replicação viral demonstrou ser necessário o desenvolvimento de novas metodologias para se poder alcançar esse intuito e a confirmação do isolamento por soroneutralização.

Palavras-chave: coronavírus bovino (BCoV), isolamento, células HmLu-1

\section{REFERENCES}

1. Benfield, D.A.; Saif, L.J. Cell culture propagation of a bovine coronavirus isolated from cows with winter dysentery. J. Clin. Microbiol., 28, 1454-1457, 1990.

2. Brandão, P.E.; Gregori, F.; Heinemann, M.B.; Lima, C.H.A.; Rosales, C.A.R.; Ruiz, V.L.A.; Jerez, J.A. Animal Coronaviruses. Virus Reviews Res., 6, 7-13, 2001.

3. Brandão, P.E.; Birgel Jr., E.H.; Gregori, F.; Rosales, C.A.R.; Ruiz, V.L.A.; Jerez, J.A. Bovine coronavirus detection in adult cows in Brazil. Arq. Inst. Biol., 69, 103-104, 2002.

4. Brandão, P.E.; Gregori, F.; Monteleone, G.S.; Soares, R.M.; Rosales, C.A.R.; Jerez, J.A. Nested assay for detection of bovine coronavirus S1 gene. Arq. Inst. Biol., 70, 1-3, 2003.

5. Cavanagh, D. The coronavirus surface glycoprotein In: SIDDELL, S. G. The Coronaviridae. Plenum, New York, 1995. p. 73-113.

6. Cyr-Coats, K. S. and Storz, J. Bovine coronavirus-induced cytopatic expression and plaque formation: host cell and virus strain determine trypsin dependence. J. Vet. Medic., 35, 48-56, 1988.

7. Dea, S.; Roy, R.S.; Begin, M.E. Bovine coronavirus isolation and cultivation in continuous cell lines. Amer. J. Vet. Res., 41, 30-38, 1980.
8. Herbert, G.A.; Pelham, P.L.; Pittman, B. Determination of the optimal ammonium sulphate concentration for the fractionation of rabbit, sheep, horse and goat antisera. Appl. Microbiol., 25, 26-36, 1973.

9. Jerez, J.A.; Brandão, P.E.; Buzinaro, M.G.; Gregori, F.; Rosales, C.A.R.; Ito, F.H.; Sakai, T. Detecção de rotavírus e coronavírus em fezes de bezerros neonatos com diarréia criados em vários municípios do Estado de São Paulo. Arq. Inst. Biol., 69, 19-23, 2002.

10. Kapil, S.; Richardson, K.L.; Maag, T.R.; Goyal, S.M. Characterization of bovine coronavirus isolates from eight states in the USA. Vet. Microbiol., 67, 221-230, 1999.

11. Ksiazek, T.G.; Erdman, D.; Golsmith C.S.; Zaki, S.R.; Peret, T.C.; Emery, S.; Suxiang, T.; Urbani, C.; Comer, J.A.; Lim, W.; Rollin, P.E.; Dowell, S.F.; Ai-Ee, L.; Humphrey, C.D.; Wun-Ju, S.; Guarner, J.; Paddock, C.D.; Rota, P.; Fields, B.; Derisi, J.; Jyh-Yuan, Y.; Cox, N.; Hudghes, J.M.; Leduc, J.W.; Bellini, W.J.; Anderson, L.J. A novel coronavirus associated with severe acute respiratory syndrome. New England J. Med., 348, 1953-1966, 2003.

12. Mebus, C.A.; Stair, E.L.; Rhodes, M.B.; Twiehaus, M.J. Neonatal calf diarrhea: propagation, attenuation, and characteristics of a coronavirus-like agent. Amer. J. Vet. Res., 34, 145-150, 1973.

13. Michaud, L.; Dea, S. Characterization of monoclonal antibodies to bovine enteric coronavirus and antigenic variability among Quebec isolates. Arch. Virol., 131, 455-465, 1993.

14. Rest, J.; Mindell, D. SARS associated coronavirus has a recombinant polymerase and coronavirus have history of host-shifting. Infect. Genet. Evolut., 3, 219-225, 2003.

15. Sato, K.; Inaba, Y.; Kurogi, H.; Takahashi, E.; Satado, K.; Omori, T.; Matsumoto, M. Hemagglutination by calf diarrhea coronavirus. Vet. Microbiol., 2, 83-87, 1977.

16. Snodgrass, D.R.; Terzolo, H.R.; Sherwood, D.; Campbell, I.; Menzies, J.D.; Synge, B.A. Aetiology of diarrhoea in young calves. Vet. Rec., 119, 31-34, 1986.

17. Spiga, O.; Bernini, A.; Ciutti, A.; Chiellini, S.; Menciassi, N.; Finetti, F.; Causarono, V.; Anselmi, F.; Prischi, F.; Niccolai, N. Molecular modelling of S1 and S2 subunits of SARS coronavirus spike glycoprotein. Biochem. Biophis. Res. Comm., 310, 78-83, 2003.

18. Takahashi, E.; Inaba, Y.; Sato, K.; Ito, Y.; Kurogi, H.; Akashi. H.; Satoda, K.; Omori, T. Epizootic diarrhoea of adult cattle associated with a coronavirus-like agent. Vet. Microbiol., 5, 151-154, 1980.

19. Toth, T.E. Trypsin-enhanced replication of neonatal calf diarrhea coronavirus in bovine embryonic lung cells. Amer. J. Vet. Res., 43, 967-972, 1982

20. Tsunemitsu, H.; Yonemichi, H.; Hirai, T.; Kudo, T.; Onoe, S.; Mori, K.; Shimizu, M. Isolation of bovine coronavirus from feces and nasal swabs of calves with diarrhea. J. Vet. Med. Sci., 53, 433-437, 1991.

21. Tsunemitsu, H. and Saif, L.J. Antigenic and biological comparisons of bovine coronaviruses derived from neonatal calf diarrhea and winter dysentery of adult cattle. Vet. Microbiol., 140, 1303-1311, 1995.

22. Yujun, R.; Chia, L.W.; Ling, A.E.; Vega, V.B.; Thoreau, H.; Se, T.S.Y.; Jerming, C.; Ng, P.; Kuo, P.C.; Landri, L.; Zhang, T.; Chan, K.P.; Ean, L.O.L.; Ng, M.L.; Sin, L.Y.; Ng, L.F.P.; Chee, R.E.; Stanton, L.W.; Long, P.M.; Liu, E.T. Comparative full-length genome sequence analysis of 14 SARS coronavirus isolates and common mutations associated with putative origins of infection. Lancet, 361, 17791785,2003 